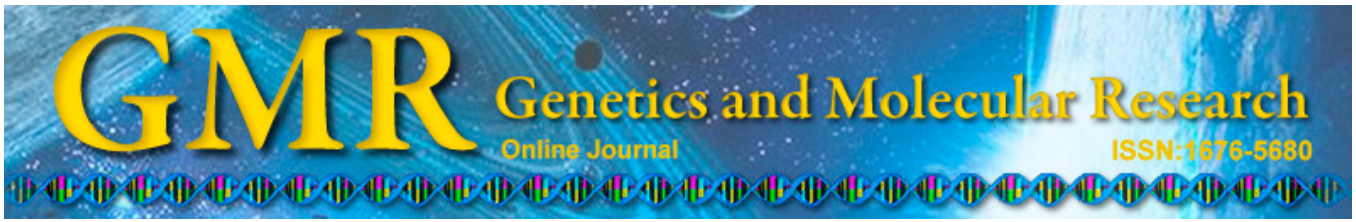

\title{
Analysis of the association between polymorphisms in the vitamin $D$ receptor $(V D R)$ gene and dental caries in a Chinese population
}

\author{
X.P. Hu' ${ }^{1,3}$, Z.Q. Li' ${ }^{1,3}$, J.Y. Zhou ${ }^{1}$, Z.H. Yu' ${ }^{2}$ J.M. Zhang ${ }^{1}$ and M.L. Guo ${ }^{1}$ \\ ${ }^{1}$ School of Stomatology, Northwest University for Nationalities, Lanzhou, \\ Gansu, China \\ ${ }^{2}$ School of Stomatology, LanZhou University, Lanzhou, Gansu, China \\ ${ }^{3}$ Key Lab of Stomatology of State Ethnic Affairs Commission, \\ Northwest University for Nationalities, Lanzhou, Gansu, China \\ Corresponding author: Z.Q. LI \\ E-mail: 122121685@qq.com
}

Genet. Mol. Res. 14 (3): 11631-11638 (2015)

Received February 9, 2015

Accepted May 15, 2015

Published September 28, 2015

DOI http://dx.doi.org/10.4238/2015.September.28.15

\begin{abstract}
Environmental influences on the development and progression of dental caries are well known; however, there is little evidence of a genetic component imparting susceptibility to dental caries. The aim of this study was to investigate the relationship between a single nucleotide polymorphism in the vitamin D receptor TaqI locus and dental caries susceptibility in a Chinese population. This casecontrol study was conducted with a case group (264 patients with dental caries from northwestern China) and a control group (219 individuals without dental caries or systemic disease from the same area). DNA was extracted from the peripheral venous blood of the study participants; the distribution of $T a q$ I locus genotypes and allele frequencies was determined via polymerase chain reaction-restriction fragment length polymorphism. The data obtained were statistically analyzed using the
\end{abstract}


Hardy-Weinberg equilibrium and Chi-square test. The frequency of the Tt genotype in the case group (14.0\%) was significantly higher than that in the control group (4.3\%), as determined using the genotype TT as the reference. The risk of dental caries was increased 3.8-fold in individuals with the heterozygous $\mathrm{Tt}$ genotype compared to that in the individuals with the TT genotype. The proportion of the ' $t$ ' allele in the case group $(7.0 \%)$ and the control group $(2.1 \%)$ was observed to be significantly different $[\mathrm{P}=0.0003 ; \mathrm{OR}=3.592$, confidence interval 95\% (1.790-7.208)]. Our results therefore suggested that the allele ' $t$ ' might be a genetic factor determining dental caries susceptibility in individuals from the northwest of China.

Key words: Vitamin D receptor; Gene polymorphism; Dental caries; Case-control study

\section{INTRODUCTION}

Dental caries is a common oral disease that affects a large number of people worldwide (Petersen, 2003); only cancer and cardiovascular disease have been known to exert a greater impact on human health. Many researchers are convinced that genetic host susceptibility might be involved in the development of dental caries in addition to the traditional quartet of susceptibility factors (bacteria, sugar, tooth tissue, and time) (Azevedo et al., 2010; Ozturk et al., 2010; Ohta et al., 2015).

The vitamin D receptor (VDR) is a nuclear biological macromolecule that mediates the biological activity of the major metabolite of vitamin $\mathrm{D}, 1 \alpha, 25$-dihydroxyvitamin $\mathrm{D}_{3}\left[1,25(\mathrm{OH})_{2} \mathrm{D}_{3}\right]$, which includes maintenance of the calcium- and phosphate balance and regulation of bone metabolism, cell differentiation, and immune response (Valdivielso and Fernandez, 2006). Vitamin D plays a major role in tooth formation, especially in the development of the enamel and dentin (Berdal et al., 1987), and controls the expression of the classical $1,25(\mathrm{OH})_{2} \mathrm{D}_{3}$ target genes and dental proteins in vivo (Papagerakis et al., 2002). The teeth of vitamin-D-deficient rats have been reported to display marked variations and abnormalities in morphogenesis and cell differentiation (Berdal et al., 1987). Furthermore, defects in the enamel and dentin have been related to hypocalcemia and hypophosphatemia, respectively, suggesting the additional role of mineral homeostasis in the tooth (Nikiforuk and Fraser, 1981). Calcification of the enamel and dentin ensured that the teeth were less prone to osteoporosis and bone demineralization, which in turn may be related to the biological characteristics of the VDR (Zhang et al., 2009). However, nutritional vitamin D deficiency or VDR gene mutation may lead to impaired functioning of the vitamin D pathway (Wharton and Bishop, 2003).

The human $V D R$ gene is located on chromosome 12; four common polymorphisms of this gene ( $T a q \mathrm{I}, A p a \mathrm{I}, B s m \mathrm{I}$, and $F o k \mathrm{I}$ ) have been previously investigated in relation to various infectious diseases and susceptibility to diabetes (Lemos et al., 2008), osteoporosis (Uysal et al., 2008), and tuberculosis (Wilkinson et al., 2000; Selvaraj et al., 2008). However, no link has been purported between this gene and caries susceptibility.

Here, we have presented a case-control study investigating the association between $V D R$ gene polymorphism and caries susceptibility in individuals with a similar socio-econom- 
ic and cultural background and access to dental care (in their respective communities) in the northwest of China.

\section{MATERIAL AND METHODS}

\section{Study populations}

All participants were permanent residents of northwestern China, and underwent their routine health examination in October 2010; the participants were recruited with the help of the Chinese Ethnic Affairs Commission. The recruited individuals were diagnosed according to the decayed, missing, and filled teeth (DMFT) index, and divided into two groups based on caries experience. The case group contained 264 people with caries experience (DMFT $\geq 1$ ), while the control group comprised of 219 individuals with no previous caries experience $(\mathrm{DMFT}=0)($ Table 1$)$.

All individuals were subjected to an oral and dental examination by two associate professors with uniform training to ensure standardization of the inspections. The DMFT score was allotted according to guidelines of the World Health Organization (1997). This study was approved by the Ethics Committee of the Northwest University for Nationalities, and informed consent was obtained from all participating individuals.

\begin{tabular}{lcc}
\multicolumn{2}{c}{ Table 1. Demographic characteristics of sample groups. } \\
\hline Category & Case group (DMFT $\geq 1)$ & Control group (DMFT $=0$ ) \\
\hline Total & 264 & 219 \\
Male & 145 & 100 \\
Female & 119 & 119 \\
Age range & $35-67$ & $30-65$ \\
Mean age & 50 & 53 \\
\hline
\end{tabular}

DMFT: decayed, missing, and filled teeth index.

\section{Sample collection and DNA extraction}

Two milliliters of blood was obtained from the median cubital vein of all individuals, and stored in vials containing ethylene diamine tetraacetic acid (EDTA) anticoagulant at $-70^{\circ} \mathrm{C}$. DNA was extracted from EDTA-anti-coagulated peripheral blood using a standard proteinase K/phenol-chloroform organic extraction method (Cristina et al., 2012). The solventextracted DNA was dissolved in Tris-EDTA buffer and stored at $-20^{\circ} \mathrm{C}$ before use.

\section{Genotyping}

The VDRTaqI(T/C) gene polymorphisms were genotyped by polymerase chain reaction-based restriction fragment length polymorphism (PCR-RFLP). The primers were designed as described in the literature (Lorentzon et al., 2000), and synthetized by Sangon Biological Engineering Technology Services Co., Ltd. (Shanghai, China). Upstream primer: 5'-CAGAGCATGGACAGGGAGCAA-3'. Downstream primer: 5'-GCAACTCCTCATGGCT GAGGTCTC-3'. The PCR system contained the template DNA (100 ng), $2.5 \mu \mathrm{L} 10 \mathrm{X}$ buffer (Geneomaga, Denver, CO, USA), $1.5 \mu \mathrm{L} 25 \mathrm{mM} \mathrm{MgCl}_{2}, 0.25 \mu \mathrm{L}$ Taq DNA polymerase (Geneomaga), $0.2 \mu \mathrm{L} 20 \mathrm{mM}$ dNTP (Geneomaga), $20 \mathrm{mM} 1 \mu \mathrm{L}$ of each upstream and downstream 
primers, and deionized water, to a final volume of $25 \mu \mathrm{L}$. The PCR conditions were set as follows: three cycles of denaturation $\left(95^{\circ} \mathrm{C}, 2 \mathrm{~min}\right)$, renaturation $\left(65^{\circ} \mathrm{C}, 90 \mathrm{~s}\right)$, and extension $\left(72^{\circ} \mathrm{C}, 1 \mathrm{~min}\right)$, followed by 32 cycles of denaturation $\left(94^{\circ} \mathrm{C}, 1 \mathrm{~min}\right)$, refolding $\left(65^{\circ} \mathrm{C}, 1 \mathrm{~min}\right)$, and extension $\left(72^{\circ} \mathrm{C}, 1 \mathrm{~min}\right)$, and a final single cycle of extension $\left(72^{\circ} \mathrm{C}, 10 \mathrm{~min}\right)$.

The PCR products $(10 \mu \mathrm{L})$ were digested with the restriction enzyme, Taq 1 (MBI Fermentas, Vilnius, Lithuania), at $65^{\circ} \mathrm{C}$ for $16 \mathrm{~h}$. The restriction digestion products were resolved on a $2 \%$ agarose gel, stained with ethidium bromide, and observed under ultraviolet light. The PCR-RFLP results were further confirmed when identical results were obtained for randomly repeated analyses of $30 \%$ of the samples.

\section{Statistical analysis}

The Hardy-Weinberg equilibrium was assessed for the VDRTaqI genotypes. Genotypic and allelic frequencies of VDRTaqI gene variants were calculated in two groups, with the odds ratio (OR) and 95\% confidence interval $(95 \% \mathrm{CI})$ representing the relative risk analysis. Data analysis was performed on the SPSS 17.0 software platform (SPSS, Chicago, IL, USA). A chi-square P value of less than $0.05(\mathrm{P}<0.05)$ was considered to be statistically significant.

\section{RESULTS}

\section{VDRTaqI gene polymorphism analysis}

All genotypes were in the range of the Hardy-Weinberg equilibrium. The frequencies of the VDR TT and Tt genotypes in the case group were 86.0 and $14.0 \%$, respectively, while those in the control group were 95.7 and $4.3 \%$, respectively. $V D R$-tt was not observed in either group.

The frequency of the $\mathrm{Tt}$ genotype in the case group (14.0\%) was significantly higher than that in the control group (4.3\%), as determined using the TT genotype as a reference. The difference between these results was statistically significant $(\mathrm{P}=0.0002)$. The risk of developing dental caries in individuals with $\mathrm{Tt}$ was increased by 3.8 times compared to individuals with TT. The proportion of the allele ' $t$ ' was $7.0 \%$ in the case group, which was significantly higher than that in the control group (2.1\%), a difference that was also found to be statistically significant $(\mathrm{P}=0.0003)$ (Table 2$)$.

Table 2. Frequency of VDRTaqI SNP genotypes and alleles in the case and control groups.

\begin{tabular}{|c|c|c|c|c|}
\hline \multirow[t]{2}{*}{ Genotype/allele } & Case group [N (\%)] & Control group [N (\%)] & \multirow[t]{2}{*}{$\mathrm{P}\left(\chi^{2}\right)$} & \multirow[t]{2}{*}{ OR $(95 \% \mathrm{CI})$} \\
\hline & $(\mathrm{N}=264 / 528)$ & $(\mathrm{N}=219 / 438)$ & & \\
\hline TT & $227(86.0)$ & $210(95.7)$ & $0.0002(13.63)$ & $3.80(1.79-8.07)$ \\
\hline $\mathrm{Tt}$ & $37(14.0)$ & $9(4.3)$ & & \\
\hline $\mathrm{T}$ & 491 (93.0) & $429(97.9)$ & $0.0003(12.95)$ & $3.59(1.79-7.21)$ \\
\hline $\mathrm{T}$ & $37(7.0)$ & $9(2.1)$ & & \\
\hline
\end{tabular}




\section{Frequency of VDRTaqI SNP genotypes by gender}

No significant differences were observed between the male and female individuals following gender-based stratification with regard to the frequency of TT and Tt genotypes (P $=0.115$; using the TT genotype as the reference). Similarly, no statistically significant genderdependent differences were observed between the two alleles $(\mathrm{P}=0.133)$ (Table 3$)$.

\begin{tabular}{|c|c|c|c|c|}
\hline \multirow[t]{2}{*}{ Genotype/allele } & Male [N (\%)] & Female [N (\%)] & \multirow[t]{2}{*}{$\mathrm{P}\left(\chi^{2}\right)$} & \multirow[t]{2}{*}{ OR $(95 \% \mathrm{CI})$} \\
\hline & $\overline{(\mathrm{N}=245 / 490)}$ & $\overline{(N=239 / 478)}$ & & \\
\hline TT & $210(85.7)$ & $192(80.3)$ & $0.115(2.488)$ & $0.681(0.422-1.100)$ \\
\hline $\mathrm{Tt}$ & $35(14.3)$ & $47(19.7)$ & & \\
\hline $\mathrm{T}$ & $455(92.9)$ & $431(90.2)$ & $0.133(2.258)$ & $0.705(0.447-1.114)$ \\
\hline $\mathrm{T}$ & $35(7.1)$ & $47(9.8)$ & & \\
\hline
\end{tabular}

\section{DISCUSSION}

A review investigating twins (Shuler, 2001) and reports of families and animal breeding (Hunt, 1944; Klein, 1946) have, together with genomics (Shelling and Ferguson, 2007), indicated dental caries to have an important genetic component. Indeed, $40-65 \%$ of caries risk has been attributed to this factor (Bretz et al., 2005). Recent studies have confirmed that the caries susceptibility of a patient may be determined by their DNA (Burgner et al., 2006; Patir et al., 2008; Peres et al., 2010; Werneck et al., 2010; Kang et al., 2011; Stanley et al., 2014), in addition to the well-known environmental factors involved in caries risk such as bacteria, diet, oral hygiene, and host factors (Lenander-Lumikari and Loimaranta, 2000; Nariyama et al., 2004; Zero, 2004).

Many years of long-term clinical observation have confirmed that high enamel calcification and density renders the teeth difficult to destroy; in addition, calcium deficiency in children has also been known to lead to a higher rate of caries than in healthy children, and also possibly to a (more) rapid decline following the onset of caries. Finally, vitamin D is known to be critical to the maintenance of a constant relationship between calcium and phosphate ions, which are key factors in the strengthening and protection of teeth. The starting point of dental caries is demineralization of the dental hard tissues, that is, the dissolution of calcium from the hydroxyapatite crystals that form the backbone of enamel (Brito et al., 2004). Ninety nine percent of the total bodily calcium has been estimated to exist in the bones and teeth. Vitamin D is a key hormone regulating the calcium metabolism, and promotes the deposition of calcium onto the teeth and bones. It also plays a key role in many physiological activities, including cell growth and differentiation, and immune and cardiovascular function. However, the activity of its receptor is influenced by polymorphisms in the VDR gene (Valdivielso and Fernandez, 2006), located in chromosome 12q13 and encoding a nuclear receptor-transcription factor. Some studies have suggested that such polymorphisms in the coding region may affect the receptor protein by altering its expression level and/or modulating its affinity for vitamin $\mathrm{D}$, which in turn modulates its calcium homeostasis and metabolism (Brito et al., 2004). Polymorphisms in the VDR gene may also affect the expression of osteoblast genes (such as osteocalcin) via the trans-acting regulation of these genes (Morrison et al., 1992), and has even been 
implicated in susceptibility to pulmonary tuberculosis (Liu et al., 2004; Sharma et al., 2011).

Here, we have conducted a preliminary study into the relationship between VDRTaqI gene polymorphisms and dental caries susceptibility in a Chinese population. The frequency of the Tt genotype was observed to be higher in individuals with caries than in those without caries; the " $t$ " allele was found to be significantly more common in the case group than in the control group. These results suggest significant correlation between the VDRTaqI gene polymorphism and caries risk in these populations; in addition, the "t" allele was considered a caries susceptibility marker. We discovered no evidence of the tt genotype in this study, which was concordant with the findings of Liu et al. (2004), but contrary to those observed by Bellamy and Hill (1998). These differences may reflect the geographic and ethnic variations.

To our knowledge, this is the first study reporting an association between VDRTaqI gene polymorphisms and dental caries, although a link between this polymorphism and periodontal disease has been reported (Brito et al., 2004). We have provided a starting point for the genotyping of caries susceptibility genes in the Chinese population; however, dental caries is likely to be influenced by multiple genetic factors. Further investigation will be required to delineate the true role of the $V D R$ gene in caries incidence, and its interactions with the environment and other susceptibility genes. Furthermore, polymorphisms in other $V D R$ gene loci that were not investigated in this study may be linked to the incidence of dental caries; however, but a single locus study lacks the statistical power for the proper analysis of these links. A study jointly analyzing multiple sites in the $V D R$ gene and/or other susceptibility genes and constructing haplotypes could greatly increase the statistical power of these investigations, and allow important associations to be definitively demonstrated for this complex genetic disease.

In summary, it could be concluded that, individuals belonging to the northwestern Chinese population expressing the heterozygous Tt genotype of the VDR TaqI gene have elevated susceptibility to caries. The " $t$ " allele may be a disease susceptibility gene for caries; however, further research into this and other putative susceptibility genes is required to delineate variations in caries experience in different genetic groups.

\section{Conflicts of interest}

The authors declare no conflict of interest.

\section{ACKNOWLEDGMENTS}

The authors would like to thank all the participants of this study and the State Ethnic Affairs Commission Key Laboratory of Oral Medicine. Research supported by the "2014" Area Fund Project of the National Natural Science Fund (\#31360124/C0309).

\section{REFERENCES}

Azevedo LF, Pecharki GD, Brancher JA, Cordeiro CA Jr, et al. (2010). Analysis of the association between lactotransferrin $(L T F)$ gene polymorphism and dental caries. J. Appl. Oral Sci. 18: 166-170.

Bellamy RJ and Hill AV (1998). Host genetic susceptibility to human tuberculosis. Novartis Found. Symp. 217: 3-13.

Berdal A, Balmain N, Cuisinier-Gleizes P and Mathieu H (1987). Histology and microradiography of early post-natal molar tooth development in vitamin-D deficient rats. Arch. Oral Biol. 32: 493-498.

Bretz WA, Corby PM, Schork NJ, Robinson MT, et al. (2005). Longitudinal analysis of heritability for dental caries traits. J. Dent. Res. 84: 1047-1051.

Brito de Júnior RB, Scarel-Caminaga RM, Trevilatto PC, de Souza AP, et al. (2004). Polymorphisms in the vitamin D 
receptor gene are associated with periodontal disease. J. Periodontol. 75: 1090-1095.

Burgner D, Jamieson SE and Blackwell JM (2006). Genetic susceptibility to infectious diseases: big is beautiful, but will bigger be even better? Lancet Infect. Dis. 6: 653-663.

Cristina CS, Mauricio SS, Armando LR, Celia SD, et al. (2012). Tumor necrosis factor alpha promoter-308G/A polymorphism in Mexican patients with patchy alopecia areata. Int. J. Dermatol. 51: 571-575.

Hunt HR, Hoppert CA and Erwin WG (1944). Inheritance of susceptibility to caries in albino rats. J. Dent. Res. 23: 385-401.

Kang SW, Yoon I, Lee HW and Cho J (2011). Association between AMELX polymorphisms and dental caries in Koreans. Oral Dis. 17: 399-406.

Klein H (1946). The family and dental disease; dental disease (DMF) experience in parents and offspring. J. Am. Dent. Assoc. 33: 735-743.

Lemos MC, Fagulha A, Coutinho E, Gomes L, et al. (2008). Lack of association of vitamin D receptor gene polymorphisms with susceptibility to type 1 diabetes mellitus in the Portuguese population. Hum. Immunol. 69: 134-138.

Lenander-Lumikari M and Loimaranta V (2000). Saliva and dental caries. Adv. Dent. Res. 14: 40-47.

Liu W, Cao WC, Zhang CY, Tian L, et al. (2004). VDR and NRAMP1 gene polymorphisms in susceptibility to pulmonary tuberculosis among the Chinese Han population: a case-control study. Int. J. Tuberc. Lung Dis. 8: 428-434.

Lorentzon M, Lorentzon R and Nordström P (2000). Vitamin D receptor gene polymorphism is associated with birth height, growth to adolescence, and adult stature in healthy Caucasian men: a cross-sectional and longitudinal study. J. Clin. Endocrinol. Metab. 85: 1666-1670.

Morrison NA, Yeoman R, Kelly PJ and Eisman JA (1992). Contribution of trans-acting factor alleles to normal physiological variability: vitamin D receptor gene polymorphism and circulating osteocalcin. Proc. Natl. Acad. Sci. U. S. A. 89: 6665-6669.

Nariyama M, Shimizu K, Uematsu T and Maeda T (2004). Identification of chromosomes associated with dental caries susceptibility using quantitative trait locus analysis in mice. Caries Res. 38: 79-84.

Nikiforuk G and Fraser D (1981). The etiology of enamel hypoplasia: a unifying concept. J. Pediatr. 98: 888-893.

Ohta M, Nishimura H and Asada Y (2015). Association of DLX3 gene polymorphism and dental caries susceptibility in Japanese children. Arch. Oral Biol. 60: 55-61.

Ozturk A, Famili P and Vieira AR (2010). The antimicrobial peptide DEFB1 is associated with caries. J. Dent. Res. 89: 631-636.

Papagerakis P, MacDougall M and Berdal A (2002). Differential epithelial and mesenchymal regulation of tooth-specific matrix proteins expression by 1,25-dihydroxyvitamin $\mathrm{D}_{3}$ in vivo. Connect. Tissue Res. 43: 372-375.

Patir A, Seymen F, Yildirim M, Deeley K, et al. (2008). Enamel formation genes are associated with high caries experience in Turkish children. Caries Res. 42: 394-400.

Peres RC, Camargo G, Mofatto LS, Cortellazzi KL, et al. (2010). Association of polymorphisms in the carbonic anhydrase 6 gene with salivary buffer capacity, dental plaque $\mathrm{pH}$, and caries index in children aged 7-9 years. Pharmacogenomics J. 10: 114-119.

Petersen PE (2003). The World Oral Health Report 2003: continuous improvement of oral health in the 21st century - the approach of the WHO Global Oral Health Programme. Community Dent. Oral Epidemiol. 31: 3-23.

Sharma PR, Singh S, Jena M, Mishra G, et al. (2011). Coding and non-coding polymorphisms in VDR gene and susceptibility to pulmonary tuberculosis in tribes, castes and Muslims of Central India. Infect. Genet. Evol. 11: 1456-1461.

Shelling AN and Ferguson LR (2007). Genetic variation in human disease and a new role for copy number variants. Mutat. Res. 622: 33-41.

Selvaraj P, Vidyarani M, Alagarasu K, Prabhu Anand S, et al. (2008). Regulatory role of promoter and 3' UTR variants of vitamin D receptor gene on cytokine response in pulmonary tuberculosis. J. Clin. Immunol. 28: 306-313.

Shuler CF (2001). Inherited risks for susceptibility to dental caries. J. Dent. Educ. 65: 1038-1045.

Stanley BO, Feingold E, Cooper M, et al. (2014). Genetic Association of MPPED2 and ACTN2 with Dental Caries. $J$. Dent. Res. 93: 626-632.

Uysal AR, Sahin M, Gürsoy A and Güllü S (2008). Vitamin D receptor gene polymorphism and osteoporosis in the Turkish population. Genet. Test. 12: 591-594.

Valdivielso JM and Fernandez E (2006). Vitamin D receptor polymorphisms and diseases. Clin. Chim. Acta 371: 1-12.

Werneck RI, Mira MT and Trevilatto PC (2010). A critical review: an overview of genetic influence on dental caries. Oral Dis. 16: 613-623.

Wharton B and Bishop N (2003). Rickets. Lancet 362: 1389-1400.

Wilkinson RJ, Llewelyn M, Toossi Z, Patel P, et al. (2000). Influence of vitamin D deficiency and vitamin D receptor polymorphisms on tuberculosis among Gujarati Asians in west London: a case-control study. Lancet 355: 618-621. 
World Health Organization (1997). Oral Health Surveys: basic methods [M]. 4th ed. Geneva: World Health Organization. 1-21. Zero DT (2004). Sugars - the arch criminal? Caries Res. 38: 277-285.

Zhang X, Beck P, Rahemtulla F and Thomas HF (2009). Regulation of enamel and dentin mineralization by vitamin D receptor. Front. Oral Biol. 13: 102-109. 